\title{
Indian Hospitals and Government in the Colonial Andes
}

\author{
GABRIELA RAMOS* \\ Newnham College, Cambridge CB3 9DF, UK
}

\begin{abstract}
This article examines the reception of the early modern hospital among the indigenous people of the Andes under Spanish colonial rule. During the period covered by this study (sixteenth to mid-eighteenth centuries), the hospital was conceived primarily as a manifestation of the sovereign's paternalistic concern for his subjects' spiritual well being. Hospitals in the Spanish American colonies were organised along racial lines, and those catering to Indians were meant to complement the missionary endeavour. Besides establishing hospitals in the main urban centres, Spanish colonial legislation instituted hospitals for Indians in provincial towns and in small rural jurisdictions throughout the Peruvian viceroyalty. Indian hospitals often met with the suspicion and even hostility of their supposed beneficiaries, especially indigenous rulers. By conceptualising the Indian hospital as a tool of colonial government, this article investigates the reasons behind its negative reception, the work of adaptation that allowed a few of them to thrive, and the eventual failure of most of these institutions.
\end{abstract}

Keywords: Hospital, Andes, Peru, Colonial, Government, Poor

In 1567, during his inspection visit to the province of Chucuito, the Spanish official Garci Diez de San Miguel questioned the local ethnic authorities about the conditions of the population under their oversight. The responses repeatedly referred to the numerous and growing payments of tribute and labour that the indigenous people of the province were obliged to provide to the Church, the colonial authorities, and the Spaniards who had settled in the region. The purpose of the inspection visit was to assess the resources of the province, compile the information necessary to set the rate of tribute, and facilitate the speedier and more abundant flow of its population's contributions in labour, silver, and products to the benefit of the Crown. The voracious colonial extractive programme would be accompanied by measures that would assert the position of the king as protector of the Indians and patron of their evangelisation. Diez de San Miguel asked the curacas (chieftains of indigenous lineage groups) if they thought that a hospital where poor

\footnotetext{
* Email address for correspondence: gr266@cam.ac.uk
}

I would like to thank Medical History's anonymous referees for their suggestions. Anne Pushkal translated this article from Spanish. Any errors and omissions are entirely my own. 
Indians could be treated should be established in the province. While some expressed their agreement, others replied that 'there was no need for a hospital'. 1

How should the curacas' refusal be understood? The rejection of an institution that at least in theory should benefit them seems baffling, although it could be interpreted as a sign of opposition to the colonial order that was attempting to take root. Since in subsequent years hospitals were established not only in this province but also in the rest of the viceroyalty, this article proposes to examine why and how this policy came about and how it was received.

As an extensive literature shows, the institution of the hospital was not originally created to address the problem of health, but rather that of poverty. ${ }^{2}$ Its point of departure and ultimate objectives were fundamentally concerned with spiritual affairs. ${ }^{3}$ The hospital offered hospitality to pilgrims and the homeless, and sheltered those who, ill or near death, had urgent need of assistance and guidance to save their souls. The hospital was not a homogeneous institution; under this name were grouped establishments and collective actions that had a number of distinct purposes and rationales for assistance. ${ }^{4}$ Their motivation was not disinterested, since it began with the premise that good works would receive divine recompense. Exported to the New World, the institution conserved some of these features, but changed its character, inasmuch as its promoters sought to express a bond between the Crown and its subjects as firm as the one between God and his faithful. In their objectives and operation, urban hospitals sought to foreground the role of health, and even that of doctors. I argue that, due to the political implications of these measures as well as for practical reasons, these objectives were difficult to attain. Because it had political and religious ends, and was, moreover, a space where distinct levels of authority and different, even discrepant visions of assistance to the poor and of the form in which it should be administered were articulated, the Indian hospital offers a privileged vantage point from which to observe the methods and institutions of government. Studying the conditions in which hospitals for Indians were established and administered allows us

${ }^{1}$ Garci Diez de San Miguel, Visita hecha a la provincia de Chucuito [Inspection of the Chucuito Province] (Lima: Casa de la Cultura, 1964), 100. For the history of the region during the colonial period, see Norman Meiklejohn, La iglesia y los lupaqa durante la colonia [The Church and the Lupaqa Under Colonial Rule] (Cuzco: Centro Bartolomé de las Casas, 1999). For an analysis of the inspection records, see John V. Murra, 'Un reino aymara en 1567 [An Aymara Kingdom in 1567]', in Formaciones económicas y políticas del mundo andino [The Economic Organization of the Inca State] (Lima: Instituto de Estudios Peruanos, 1975), 193-223.

${ }^{2}$ George Rosen, 'The hospital: historical sociology of a community institution', in G. Rosen (ed.), From Medical Police to Social Medicine: Essays on the History of Healthcare (New York: Science History Publications, 1974), 274-303. J. Henderson, P. Horden and A. Pastore (eds), The Impact of the Hospital 300-2000 (London: Peter Lang, 2007); Mary Lindemann, Medicine and Society in Early Modern Europe (Cambridge: Cambridge University Press, 1999); Guenter B. Risse, Mending Bodies, Saving Souls: A History of Hospitals (New York and Oxford: Oxford University Press, 1999); Alejandra Piñeyrúa, 'Caridad cristiana, asistencia social y poder político: las instituciones hospitalarias en España (siglos XIII al XIV) [Christian Charity. Social Assistance, and Political Power: Hospitals in Spain (13th to 14th Centuries)]', in M. E. González de Fauve and P. de Forteza (eds), Ciencia, poder e ideología: el saber y el hacer en la evolución de la medicina española [Science, Power, and Ideology: Knowledge and Practise in the Evolution of Spanish Medicine] (Buenos Aires: Universidad de Buenos Aires, 2001), 61-107.

${ }^{3}$ Peregrine Horden, Hospitals and Healing from Antiquity to the Later Middle Ages (Ashgate: Variorum, 2008). See especially 'A non-natural environment: medicine without doctors and the medieval european hospital', 133-45.

${ }^{4}$ Piñeyrúa, op. cit. (note 2); Miri Rubin, 'Imagining medieval hospitals: considerations on the cultural meaning of institutional change', in J. Barry and C. Jones (eds), Medicine and Charity Before the Welfare State (London: Routledge, 1991), 14-25; Juan Ignacio Carmona García, El sistema de hospitalidad pública en la Sevilla del Antiguo Régimen [The Public Hospital System in Ancien Régime Seville] (Seville: Diputación Provincial, 1978); Lindemann, op. cit. (note 2), 123-7. 
to approach a field of conflict and negotiation where matters of religion, subsistence, and governance overlapped. Using judicial and administrative sources produced by civil and church governments, I focus on hospitals located outside of the viceregal capital between the sixteenth and eighteenth centuries. ${ }^{5}$

\section{Poverty and the Poor in Catholic Europe: Tradition and Reform}

Until the sixteenth century there predominated in Europe a point of view that saw nothing alarming about the existence of the poor: they were even considered necessary to the exercise of the Christian virtue of charity and made possible the salvation of those who helped them. But soon different attitudes appeared, in which the poor were perceived as a threat to the well being of society. The role that the elites and the monarch were to play in this regard was also the subject of debate. On the one hand were those who defended the visibility of the poor and supported their right to solicit alms, defended the practice of charity, and reaffirmed the traditional role of the Church as protector of the poor. On the other hand were those who considered the poor and poverty as anomalies, invoked the intervention of the State, and advocated plans for social reform which contemplated the creation of places of confinement where the poor would be compelled to work. ${ }^{6}$ It has been maintained that the lay and reformist policies initiated by the municipalities to confront poverty were successful in Protestant northern Europe, while in southern Europe there persisted an attitude that was traditional, Catholic, and archaic. ${ }^{7}$ However, this dichotomy has been questioned by historians who have shown that cities like Venice, profoundly Catholic and possessing a strong lay government, had a firm grasp on actions of social welfare. $^{8}$

Studies of Spanish cities like Toledo, Seville, and Madrid show that, during the sixteenth and seventeenth centuries, the Crown tried to push forward social reforms and exercise a certain control over the provision of relief to the poor. To this end, it sought to reduce the number of hospitals and intervene in their administration and governance. ${ }^{9}$ These plans met with resistance and difficulties of varying calibre, and the impulse weakened. Before

\footnotetext{
${ }^{5}$ Adam Warren's, Medicine and Politics in Colonial Peru: Population Growth and the Bourbon Reforms (Pittsburgh: University of Pittsburgh Press, 2010) provides in its first chapter an overview of the beginnings of colonial hospitals in Lima and the medical ideas professed by physicians under the Habsburgs. However, the actual timeframe of his study begins in the mid-eighteenth century (when this article ends) up to the midnineteenth century, long after Peru's independence.

${ }^{6}$ Jon Arrizabalaga, 'Poor relief in Counter-Reformation Castile: an overview', in O.P. Grell and A. Cunningham (eds), Health Care and Poor Relief in Counter-Reformation Europe (London: Routledge, 1999), $157-8$.

${ }^{7}$ Elena Maza Zorrilla, Pobreza y asistencia social en España, siglos XVI al XX [Poverty and Social Assistance in Spain, 16th to 20th Centuries] (Valladolid: Universidad de Valladolid, 1987); Félix Santolaria Sierra, El gran debate sobre los pobres en el siglo XVI. Domingo de Soto y Juan de Robles 1545 [The Great Debate about the Poor in the 16th Century] (Barcelona: Ariel, 2003); José Antonio Maravall, Antiguos y modernos: visión de historia e idea de progreso hasta el renacimiento [Traditionalists and Modernists: Perceptions of History and the Idea of Progress up to the Renaissance] (Madrid: Sociedad de estudios y publicaciones, 1966); José Antonio Maravall, Utopía y reformismo en la España de los Austrias [Utopia and Reformism in Habsburg Spain] (Madrid: Siglo XXI, 1982); Bronislaw Geremek, Poverty: A History (Oxford: Blackwell, 1994).

${ }^{8}$ Brian Pullan, Rich and Poor in Renaissance Venice: The Social Institutions of a Catholic State, to 1620 (Oxford: Basil Blackwell, 1971); Brian Pullan, 'Catholics and the Poor in Early Modern Europe', Transactions of the Royal Historical Society, 26 (1976), 15-34; Rober Jütte, Poverty and Deviance in Early Modern Europe (Cambridge: Cambridge University Press, 1994).

${ }^{9}$ Carmona García, op. cit. (note 4), 200-5; Linda Martz, Poverty and Welfare in Habsburg Spain: The Example of Toledo (Cambridge: Cambridge University Press, 1983); Teresa Huguet-Termes, 'Madrid Hospitals in the Context of the Hapsburg Empire', Medical History Supplement, 29 (2009), 64-85; Arrizabalaga, op. cit. (note 6).
} 
the eighteenth century no state-led system of poor relief emerged, and those initiatives that did exist depended on local policy. Although the monarchy was faithful to its role as head of Catholicism and the Counter-Reformation in Europe, in its attempt to control the hospitals and become patron of the poor it remained in continuous tension with the Church. It is worth examining whether these debates and efforts at reform had any repercussions in the New World.

\section{The King's Sovereignty and the Invention of the Miserable Condition of the Indian}

As we know, papal bulls sanctioned Spain's sovereignty over the inhabitants of the New World. Shortly thereafter, the Patronato Real (rights and privileges of the Crown over Church affairs) would be established as the foundation of an intimate cooperation between Church and State in the colonial enterprise, which upheld the role of the king as the sponsor of missionary activity and protector of the Indians. The Indians, because they were pagans and new to the Christian faith, were legally considered miserables (wretches). Originally, this condition implied not only poverty, but also the inability to be responsible for one's own fate. The root of the problem was spiritual: the Indians' lack of knowledge of the true faith made them incapable of controlling their passions or distinguishing between good and evil. Thus they had a proclivity for vice, to being deceived by the devil, and to slipping back into their old religion. As miserables, as morally impoverished, and as minors, the Indians fell under the king's protection. ${ }^{10}$

The documents in which the colonial authorities directly address the Indians refer to this role of the king. In 1575, when the viceroy Toledo called together the curacas of Arequipa, Cuzco, and Collao to explain their duties as authorities, he culminated his address by saying, 'That they and others, being poor, are the King's vassals, and because they are so, His Majesty has them for children'. ${ }^{11}$ The concept of government revealed here, as Mitchell Dean affirms, is of 'patriarchal relations of service and obligation between sovereign and subjects, heads of family and wives, parents and children, masters and servants, and so on down the line'. ${ }^{12}$ Government, sovereignty, and aid are three concepts that presuppose sociopolitical linkages whose form and nature I am interested in exploring.

The position of the king as protector of the poor was always unstable. The Church, invoking tradition and ecclesiastical law, also claimed this role for itself. In the realm of poor relief, this rivalry was made manifest in the creation and functioning of the Indian hospitals.

\footnotetext{
${ }^{10}$ Castañeda Delgado Paulino, 'La condición miserable del indio y sus privilegios [The Condition of the American Indian as Wretched and its Associated Privileges]', Anuario de Estudios Americanos [Yearbook of American Studies], 28 (1971), 245-335. In her study of poverty in eighteenth-century Ecuador, Cynthia Milton shows that the concept of poor without losing its moral connotation acquired a decidedly economic meaning. The Many Meanings of Poverty: Colonialism, Social Compacts, and Assistance in Eighteenth-Century Ecuador (Stanford: Stanford University Press, 2007) 92, 140.

${ }^{11}$ G. Lohmann Villena and M. J. Sarabia Viejo (eds), Francisco de Toledo: Disposiciones gubernativas para el virreinato del Perú 1575-1580 [Francisco de Toledo's Regulations for the Government of the Viceroyalty of Peru 1575-1580], 2 vols (Seville: Escuela de Estudios Hispanoamericanos, 1986-9), Vol. 2: 95. For a similar description of the king's paternal role in France, see Tim McHugh, Hospital Politics in Seventeenth-Century France: The Crown, Urban Elites and the Poor (Aldershot: Ashgate, 2007), 50.

12 Mitchell Dean, 'Pastoral power, police and reason of state', in Mitchell Dean (ed.), Governmentality: Power and Rule in Modern Society (Los Angeles: Sage Publications, 1999), 89-116, 93.
} 


\section{The Hospitals for Indians in Government Policy}

From a very early date, the Crown issued instructions to the viceroys, audiencias (royal supreme courts with administrative duties), and governors to establish hospitals. ${ }^{13}$ However, rather than being a manifestation of the new ideas about social policy that had begun to appear in the intellectual debate in Spain, the founding of hospitals appears to reflect the policy followed during the Reconquest: closely tied to military activity, the occupation of territory, and the religious conversion of the recently conquered population. ${ }^{14}$

While the Indian hospital of Lima was begun at the initiative of its archbishop in 1548, those of the principal viceregal cities such as Trujillo (1551), Piura (1553), Cuzco (1556), and Huamanga (1556) were created by order of their town councils. ${ }^{15}$ All invoked charity, but the emphasis varied. In Lima, the indigenous population increased markedly due to the migrations that followed the conquest. Regardless of whether they were permanent or temporary, many migrants lost the ties that had connected them to their places of origin, leaving them exposed to illness, hunger, and violence. The attitude of the Spanish in the face of the Indians' plight reveals their doubts about the pertinence of being charitable to non-Christians or to those recently converted to Christianity. Fray Domingo de Santo Tomás denounced to the king the indifference of many to the spectacle of corpses abandoned in the streets, and demanded royal support for the recently founded Indian hospital of Santa Ana. ${ }^{16}$ The chronicler Fernando de Montesinos affirms that in Cuzco the conquistadors soon acknowledged that, since they were benefitting from the Indians' labour, it behoved them to concern themselves with the growing number of paupers populating the city. Organisers in the town council founded the hospital, undertook its patronage, and provided it with property. ${ }^{17}$ Both cities shared the concern for public order and the control of the poor.

Because it was considered first and foremost a place for the cure of souls, the Church claimed control of the hospital. In Lima, although the institution belonged to the Patronato Real, the archbishop Jerónimo de Loayza sought to block the involvement of laymen. His reasons were based upon medieval tradition, but also on more recent ecclesiastical dispositions. For some centuries past, the bishops had had the right to supervise and inspect the hospitals, but what was more, the recently concluded Council of Trent had validated this faculty. ${ }^{18}$ Upon learning that the town council of Lima was preparing to comply with

\footnotetext{
${ }^{13}$ Recopilación de leyes de los reinos de las Indias [Compilation of the Laws of the Kingdoms of the Indies], 4 vols (Madrid: Cultura Hispánica, 1973), Vol. 1: Título Cuarto, Ley Primera.

${ }^{14}$ Carmona García, op. cit. (note 4), 25.

${ }^{15}$ Francisco Guerra, El hospital en Hispanoamérica y Filipinas [The Hospital in Spanish America and the Philippines] (Madrid: Ministerio de Sanidad y Consumo, 1994), 430-9.

${ }^{16}$ Manuel Olmedo Jiménez, 'El hospital de Santa Ana de Lima durante los siglos XVI y XVII [The Santa Ana Hospital of Lima during the 16th and 17th Centuries]', in Actas del III Congreso Internacional sobre los Dominicos y el Nuevo Mundo (Madrid: Deimos, 1991) [Proceedings of the Third International Congress on the Dominicans and the New World], Gabriela Ramos, Death and Conversion in the Andes: Lima and Cuzco, 1532-1670 (Notre Dame, IN: University of Notre Dame Press, 2010), 102-3.

${ }^{17}$ Fernando de Montesinos, Anales del Perú [Annals of Peru], in Víctor M. Maúrtua (ed.), 2 vols (Madrid: Imprenta de Gabriel L. y del Horno, 1906 [1642]), 1:234. Diego de Esquivel y Navia, Noticias cronológicas de la gran ciudad del Cuzco [News of the Great City of Cuzco Organized in Chronological Order], 2 vols (Lima: Fundación Augusto N. Wiesse, 1980), Vol. 1: 220.

18 While in France the monarchy did not receive this and other decrees from the Council of Trent, in Spain King Philip II accepted the decrees as state law. Thus the bishops' authority over the hospitals went unquestioned. On Spain, see Carmona García, op. cit. (note 4), 69, and on France, see Jean Imbert, 'Les prescriptions hospitalières
} 
the king's call to merge the hospitals, Loayza countered that to do so would betray the will of the benefactors of Santa Ana, since the hospital for Spaniards could not benefit from its assets. $^{19}$

After the first foundations of hospitals for Indians, the elites of the principal cities of the Peruvian viceroyalty continued to participate in their governance, but did not retain control of them, as some theorists and rulers of the early period appear to have wanted originally. In his Gobierno del Perú (1567), the oidor (magistrate and royal official) Juan de Matienzo underscored the hospitals' value as civilising institutions and as institutions of government. In a short passage he suggests that he considered the city of Venice's system of public assistance as an example to be imitated. It is possible that Matienzo may have been referring to its lay leadership. Perhaps he found attractive the fact that, in Venice, the goods that were distributed to the needy came for the most part from the community rather than from the collection of alms. ${ }^{20}$

\section{The Toledan Administration and the Indian Hospitals}

The general inspection visit of the viceroy Toledo, begun in 1569, prompted the founding of hospitals in various parts of Peru, establishing hospitals for Indians in cities such as Potosí, La Plata, La Paz, and Huancavelica. The ordinances issued by the viceroy reveal the influence of Matienzo and his interest in the lay leadership of the hospitals. Upon founding the hospital of La Plata, Toledo organised the city's notables into a brotherhood which would supervise its operation; the oidor Matienzo himself was one of its members. ${ }^{21}$ In the directives for the hospital in Potosí, Toledo recommended the appointment of deputies in charge of overseeing its administration, and ordered that it be placed under the supervision of the corregidor (magistrate). ${ }^{22}$

The intervention of the viceroy indicated a shift in the attitude of the state, the Church, and the elites toward their responsibility to the poor. Matienzo explained that they were obliged to offer assistance to the Indians: 'since all we who inhabit this kingdom eat by [means of] their sweat'. ${ }^{23}$ These ideas were far removed from any concern for social justice, though, since the motives for helping the Indians were eminently pious. ${ }^{24}$ At the same time, it was argued that the support of the institutions that would assist the Indians would be their own responsibility. The resources to maintain the hospitals would come from the communities.

Three salient issues emerge from the creation and administration of the hospitals for Indians: the manner in which they were justified by the colonial functionaries; the consequences that the organisation of the hospitals had upon their supposed beneficiaries; and finally, how they were received, especially among the indigenous population. Although I will refer to those hospitals located in the most important cities of the

du Concile de Trente et leur diffusion en France [The Rulings about Hospitals Issued by the Council of Trent and Their Propagation in France]', Revue d'Histoire de l'Église de France [Journal of the History of the French Church], 42 (1956), 5-28.

19 Olmedo Jiménez, op. cit. (note 16), 585.

${ }^{20}$ Brian Pullan, Rich and Poor, op. cit. (note 8), 239; Juan de Matienzo, Gobierno del Perú [Government of Peru] (Lima: Institut Français d'Études Andines, 1967), 74.

${ }^{21}$ Lohmann Villena and Sarabia Viejo, op. cit. (note 11), Vol. 1: 455-6.

22 Lohmann Villena and Sarabia Viejo, op. cit. (note 11), Vol. 2: 14-15, 17.

23 Matienzo, op. cit. (note 20), 79.

${ }^{24}$ MacHugh, op. cit. (note 11), 21-2. 
viceroyalty, my focus is the rural and provincial hospitals, whose existence is practically unknown. ${ }^{25}$

The arguments justifying the existence of Indian hospitals in the sixteenth century varied remarkably over the course of a period of little more than twenty years. The contrasts reveal changes in colonial policy and administration, and also show how the Spaniards perceived the response of the Andean population to the profound calamity brought about by the conquest. While in the 1540s friars like Domingo de Santo Tomás called for the king's support of the hospital, citing the abuses of the Spaniards and their lack of compassion, in later years the predominant discourse that explained why the hospitals were necessary alleged a supposed lack of charity among the Indians. Toward the end of the 1560s, before Toledo arrived in Peru, a feeling of hostility towards the Indians grew among the colonial and ecclesiastical authorities, and was reflected in the writing of history, in the studies of local religion, in manuals for evangelisation, and in political treatises. This attitude has been explained by the need to justify the conquest and to give substance to the Spanish crown's claims to sovereignty since, it was argued, it had liberated the indigenous people from the 'tyranny' of the Incas. In his treatise on Inca religion, Polo de Ondegardo wrote that Andeans did not have charitable feelings and scorned the elderly and the poor. ${ }^{26}$ For his part, Matienzo asserted that the Indians had little compassion for their neighbours, did not help each other, and failed to attend to the sick, the elderly, or those unable to work, not even when it came to their own relatives. ${ }^{27}$

When Toledo issued ordinances for the foundation of hospitals in the Andes, he essentially reproduced Ondegardo's words and especially those of Matienzo about the purported Andean attitudes toward the poor. The ordinances for the hospital of La Plata, issued in 1574, underscored the need to inculcate the practice of charity among the Indians to facilitate their conversion to Christianity. In this text, Toledo asserted that never before had there existed anywhere people as devoid of charitable instincts as the Andeans. He maintained that in Peru one saw parents who had no regard for their children, and vice versa. It was imperative to teach the Indians to have compassion for the weak, and the hospitals were a means of accomplishing this. ${ }^{28}$

The image of poverty, of the poor, and of assistance that emerges from these testimonies is disconcerting. It is not easy to understand what prompted men like Ondegardo and Matienzo to describe the way Andeans treated the poor in such terms. It is possible that, in the years following the conquest, in various parts of the Andes, the weakest had been left unprotected. Such an attitude would have reflected the conditions of extreme penury to which many men and women saw themselves reduced. One might imagine then that, seeing the effects of so profound a crisis, Ondegardo and Matienzo mistook certain survival strategies for social norms.

The perception of the existence of widespread poverty as well as the objectives of evangelisation and spiritual reform justified the founding of hospitals, not just in the most important urban centres, but also in the provinces and rural areas. Prior to Toledo's tenure,

\footnotetext{
${ }^{25}$ Studies on colonial hospitals in Peru focus on the city of Lima only. See for example Miguel Rabí Chara, Del hospital de Santa Ana (1549 a 1924) al hospital Nacional Arzobispo Loayza (1925 a 1999): 450 años de protección de la salud de las personas [From the Santa Ana Hospital (1549 to 1924) to the National Hospital Arzobispo Loayza (1925 to 1999): 450 Years Taking Care of People's Health] (Lima: n.p., 1999).

${ }^{26}$ Polo de Ondegardo, 'Los errores y supersticiones de los indios [The Errors and Superstitions of the Indians]', Revista Histórica (Lima), 1 (1906), 207-31, 209.

27 Matienzo, op. cit. (note 20), 18.

${ }^{28}$ Lohmann Villena and Saravia Viejo, op. cit. (note 11), Vol. 1: 453.
} 
the hospitals' sources of support generally came from alms and bequests, as was customary in Europe. Chucuito is among the first provinces we know of in which community assets were applied to the costs of health care. ${ }^{29}$ This measure would become widespread a short time afterwards, when Toledo ordered that a portion of indigenous tribute, known as the tomin de hospital, be earmarked to support the Indian hospitals. ${ }^{30}$ It seems that this decision, too, was influenced by Matienzo's opinion on the advisability of utilising community resources in preference to depending on almsgiving. The commentary about charity being an attitude unknown in the Andes must have served as a basis for the existence of the tomin de hospital: the payment of this contribution not only solved a practical problem, but would also serve to ensure that the Indians learned the meaning of this virtue. Thus in the New World changes were introduced which in Spain at the time would have been impractical or even inconceivable: that alms would come mainly out of the pockets of the poor. Moreover, while in Europe there was talk of creating houses where the poor would be confined and compelled to work to earn their keep, in the Andes it seems the principle being put into practice was that the Indians should leave their towns to work and help themselves. ${ }^{31}$

The fact that hospital care was to depend upon Indian contributions soon had consequences for indigenous assets. During the smallpox epidemic that struck the Peruvian viceroyalty between $1588-9$, the viceroy directed that money be taken from the funds of the communities of the Lima diocese as a loan to the hospital of Santa Ana. Contributions totalling 2,000 pesos were collected, a significant sum given the penury which the epidemic must have engendered among the native population. ${ }^{32}$ The negative consequences of the epidemic for the indigenous population of Lima did not end there. Five years later, the doctor Marco Antonio Gentil sued for breach of contract, claiming the Indians had not paid his salary. Gentil maintained that he had originally been nominated in 1580 by Toledo, but for various reasons did not fulfil his duties. Confirmed by the viceroy Villar in 1587, Gentil asserted that he had attended the Indians of the reducciones (settlements to which the native population had been removed) that surrounded the city of Lima, and was now claiming his payment in money, foodstuffs, and livestock. The curacas of Lima, represented by the protector de naturales (a royal official charged with protecting Indian interests) rejected the claim. They contended that Gentil only appeared in the towns on feast days when 'he idled about with the Indians'. They added that Gentil neither visited the sick nor enquired after them. Finally, they said that it was their understanding that the doctor had been contracted for the years of the epidemic, but this had not entailed a permanent obligation. The arguments of the protector de naturales were rejected and the judge ruled that the Indians had to pay the fees claimed by Gentil. ${ }^{33}$ Clearly the

\footnotetext{
${ }^{29}$ Diez de San Miguel, op. cit., (note 1), 259.

${ }^{30}$ In Mexico a portion of the Indian head tax, known as 'medio real del hospital', was used to support the hospitals. Josefina Muriel, Hospitales de la Nueva España [Hospitals of New Spain], 2 vols (México: Universidad Nacional Autónoma de México, 1990), Vol. 1: 138.

${ }^{31}$ A few years later, viceroy Toledo stipulated that the profits generated by encomiendas without holders be assigned to the hospital of Santa Ana. However, these revenues were neither safe nor permanent. Lewis Hanke and Celso Rodríguez (eds), Los virreyes españoles en América durante el gobierno de la Casa de Austria [The Spanish Viceroys in America under the Habsburgs], 7 vols. Biblioteca de Autores Españoles [Spanish Authors Library] (Madrid: Atlas, 1978-80), Vol. 2: 66-7.

32 Archivo General de la Nación del Perú (from now on AGN), Derecho Indígena, Leg. 3, c.31. On epidemics in colonial Peru and their effects on the indigenous population, see Noble David Cook, Demographic Collapse: Indian Peru, 1520-1620 (Cambridge: Cambridge University Press, 1981).

33 AGN, Derecho Indígena, leg. 3, c.33.
} 
appointment Toledo had made and the payment the doctor demanded represented an expense over and above that comprised by the tribute and its fraction, the tomin de hospital. ${ }^{34}$

The creation of systems of assistance and the establishment of hospitals in the provinces of the viceroyalty were also implicated in the undermining of indigenous systems of authority. As he passed through the province of Chucuito some years after the visit of Diez de San Miguel, Toledo issued instructions for the management of its community funds. ${ }^{35}$ To a certain degree, these directives were adjusted to the particular circumstances of the place, even as they were altering them. The objectives of the ordinances were basically twofold: to safeguard resources that would serve to meet tribute payments in the event that the settlers were unable to do so, and to provide a means of supporting those who could not work. The appointment of a Spanish administrator seems to have had as its objective the weakening of the native authorities. Faced with the difficulties of administering the resources of so extensive a province, the Toledan ordinances resorted to indigenous support, but bypassed the curacas. It is worth noting that these instructions amply elaborated the themes of administration and assistance in a communal context, but were not specifically concerned with the hospital, an institution that was mentioned only in passing.

The examples that we have seen here place squarely before us a series of diverse social practices as much as they do an institutional reality. Below, we will consider the hospitals that were created in the cities, but we are especially interested in understanding what took place in the smallest districts. We should investigate what kind of hospitals existed in these places, and how they worked.

\section{The Varied Faces of the Indian Hospitals}

The European notion of the hospital that was exported from Spain to the Andes had contrasting components. First, it bore features of the Spanish medieval institutions which had proliferated in urban centres, although also in the country and along the pilgrimage routes: houses that offered shelter and a bit of nourishment, where medical attention was secondary to the spiritual services provided by members of the religious orders or by devout persons. These establishments were supported by alms originally provided by their founders and ordinarily procured by their administrators. Second, the concept also included the urban hospitals whose objectives were not sharply differentiated from those of the establishments just described, but in which the role of doctors was considerably more important: examinations and licences were required to practice, although the need for traditional healers continued. ${ }^{36}$ In the New World such institutions were placed under royal patronage, where they remained in the care of the viceroys and were subject to the scrutiny of the bishops. In both Europe and the New World, hospitals were often established in buildings specifically constructed for that purpose. These mostly urban

\footnotetext{
34 Juan B. Lastres, 'Una epidemia en el siglo XVI [An Epidemic in the 16th Century]', Revista del Archivo Nacional del Perú [Journal of the National Archives of Peru], 19 (1955), 267-77.

${ }^{35}$ Lohman Villena and Sarabia Viejo, op. cit. (note 11), Vol. 2: 73-90.

36 The Real Tribunal del Protomedicato, a body in charge of supervising medics, was founded in 1568. Juan B. Lastres, Historia de la medicina peruana [History of Peruvian Medicine], 3 vols (Lima: Imprenta Santa María, 1951), Vol. 2: 57-8. See also John T. Lanning, The Royal Protomedicato: The Regulation of the Medical Professions in the Spanish Empire (Durham, N.C.: Duke University Press, 1985). Although documentation is scarce, it seems that indigenous healers were not uncommon among the empiricists working in the hospitals for Indians. Esquivel y Navia, op. cit. (note 17), Vol. 2: 48.
} 
institutions bore a little more resemblance to modern hospitals. Finally, for reasons of space, social hierarchies, cultural differences, and even political expediency the Spanish hospital 'system' permitted the assistance of the sick in their houses via the distribution of food and, exceptionally, the visit of a doctor, surgeon, or barber. In sum, in the European concept of the hospital that was established in the Andes there coexisted different manifestations of the idea of assistance that reflected diverse circumstances, social relations, and interpretations of the jurisdictions involved. ${ }^{37}$

The hospital for Indians in Lima and others established in the principal cities of the viceroyalty had some features of the Crown-sponsored institutions that had emerged in the Habsburg period, ${ }^{38}$ but while they were governed by certain common principles, they were not part of institutional networks. Many of the hospitals which were created in the environs of the capital and in the interior of the viceroyalty languished and eventually disappeared, while others were adapted to local circumstances and remained in operation at least until the time of the Bourbons.

The documentation on provincial hospitals is very scanty. It is dispersed in various repositories, and the information it offers is frequently unclear. Notwithstanding the disappearance of some papers and the classification of others in unexpected places, the picture that the archives offer the historian represents a tangle of complicated interests, precarious administration, conflicts of jurisdiction, and different approximations of the idea of the hospital that existed in colonial Peru. Because the hospitals were identified with the governments of their respective localities, neither the viceroy nor the audiencias commissioned reports on the number and status of these establishments for an entire corregimiento or province. In the memorias of the viceroys the references to hospitals are usually found in the section called 'ecclesiastical government'. The visitas pastorales (reports of diocesan visitations) certainly include this sort of information, although it tends to be minimal.

The reports compiled during the inspection visits of the Archbishop Toribio de Mogrovejo to the then far-flung diocese of Lima between the end of the sixteenth century and the beginning of the seventeenth reveal the conflicts of jurisdiction, the different points of view on what constituted the proper scope of the hospital, and the lack of specificity about the sources of its support, circumstances that would persist in the decades that followed. In 1585 the priests in charge of the doctrinas (Indian parishes) of the province of Huaylas presented a memorial (written statement) describing the difficult state of their parishes and of the hospitals within this jurisdiction. They deplored the fact that, although there were sufficient resources with which to build them, the Indians 'died like beasts' in the fields for lack of hospitals. The religious superior of the province explained in a letter to the archbishop that, as long as there were no hospitals, nor the "necessary cleanliness' for the divine cult (in other words, to say Mass and administer the sacraments properly), the priests would not provide spiritual assistance to the Indians. ${ }^{39}$ The curates'

\footnotetext{
${ }^{37}$ Manuel Josef de Ayala, Diccionario de gobierno y legislación de Indias [Dictionary of Government and Legislation of the Indies], 13 vols (Madrid: Instituto de Cooperación Iberoamericana/Ediciones de Cultura Hispánica, 1989-96), Vol. 7: 144-5, explains the differences between the hospitals according to their source of support: royal patronage, taxes, private patronage, alms, and bequests.

38 Madrid's General Hospital possibly represented a model for the hospitals established in Spanish America. See Huguet-Termes, op. cit. (note 9), 76.

${ }^{39}$ Emilio Lissón, La Iglesia de España en el Perú [The Church of Spain in Peru], 5 vols (Sevilla: Católica Española, 1943-7), Vol. 3: 337, 359. The clergyman seems to imply that the Indians' homes did not fulfil the criteria of 'cleanliness' necessary to administer the sacraments.
} 
complaints singled out the corregidores, whom they accused of appropriating community funds which, they argued, should have gone to the adornment of the churches and the equipping of the hospitals. When Mogrovejo himself asked the corregidor of Cajatambo for the money for the completion of the province's churches as well as for beds and medicine for the hospitals, the latter refused to give it to him. ${ }^{40}$ The archbishop then opted to excommunicate him. ${ }^{41}$ The dispute between the corregidor and the parish priests for the resources of the community exemplifies the difficulties that arose from putting into practice the principals of the Patronato Real, as well as determining the character of the hospitals in the doctrinas. ${ }^{42}$

The observations under the heading of 'hospital' in the registers of the pastoral visits that took place between 1593 and 1606 under the heading of 'hospital' list only their property. In practically every case, there appear small quantities of livestock. Other income, such as money from annuities and rentals, appears only very exceptionally. The income derived from the tomin - the cause of the incident of 1585 - is not mentioned, nor is there any indication of what the corregidores did with it. ${ }^{43}$ Remarkably, hospital buildings receive practically no mention, and not all the towns visited had property assigned to this category. In no case is there any mention of persons responsible for attending to the sick. In light of later sources, one might conclude that the hospitals that Mogrovejo had visited did not exist, at least not in a form that would correspond to the urban model. The livestock that they possessed was used to feed the sick who were cared for in the their homes. It is likely that in at least some cases this help was administered according to the membership of the beneficiary in some particular kinship group. ${ }^{44}$ These hospitals appear to represent actions more than they do establishments. They bear more resemblance to the domestic, barely medicalised version, but not to the institution that the Habsburgs sponsored in the sixteenth century. Their principal source of funding was the community funds like those regulated by Toledo in Chucuito.

The report commissioned in 1619 by the archbishop Bartolomé Lobo Guerrero contains one of the most complete pictures of the state of the hospitals in the Indian parishes of the diocese of Lima and reveals marked contrasts with regard to Mogrovejo's visit. The idea of the hospital that the inspectors had is clear: it should be an establishment that met certain minimum conditions for tending to the sick. For this reason, the document describes what the inspectors found on their tour: in the great majority of cases a series of empty houses that were called a 'hospital'. ${ }^{45}$ While in Mogrovejo's inspection visit some Indian parishes had premises designated to serve as a hospital along with some goods, the

${ }^{40}$ Ibid., Vol. 3: 334-5.

${ }^{41}$ Lissón, op. cit. (note 39), Vol. 3: 349-72.

${ }^{42}$ Lissón, op. cit. (note 39), Vol. 3: 451-2; Hanke and Rodríguez, op. cit. (note 31), Vol. 1: 234-5.

43 José Antonio Benito (ed.), Libro de visitas de Santo Toribio de Mogrovejo 1593-1605 [Records of Santo Toribio de Mogrovejo's Pastoral Visitations 1593-1605] (Lima: Pontificia Universidad Católica del Perú, 2006), 367.

${ }^{44}$ For example, the herds belonging to the rural parish of Huañec, Yauyos, are described as the property of two different kin groups (ayllus), Huañec and Llacuaz, respectively. Benito, ibid., 212. Historians of Africa and Europe have highlighted the importance of kin groups and of family structures for the study of poverty and social assistance. John Iliffe, The African Poor (Cambridge: Cambridge University Press, 1987), 8; Peregrine Horden, 'Family history and hospital history in the middle ages', in P. Horden (ed.), op. cit. (note 3), 146-282.

${ }^{45}$ For example, the hospital of the rural parish of Los Reyes de Chinchaycocha, with a population of 2,100, was listed as 'deserted'. Lissón, op. cit. (note 39), Vol. 5: 292. 
parishes in Lobo Guerrero's report lacked both and appeared never to have had them. ${ }^{46}$ Of the 152 places visited, which includes some towns in which Spaniards and Africans also lived, in fifty-seven there was no hospital, and in twenty-one the inspectors left no clear indication of whether one existed, although probably none did. Of the seventy-four remaining villages that did have a hospital, in sixty-three cases the inspectors indicated that these were deserted or that the inhabitants did not want to make use of them. In the localities with hospitals to which Indians did resort, these were not for their exclusive use, but rather were 'multi-racial' and urban or semi-urban, as in the case of the coastal towns of Santa, Cañete, Ica, and Chancay, or the city of Huánuco in the central sierra. Barely a handful of hospitals in the Indian parishes functioned according to the inspectors' criteria: in Pacarán, some residents made use of the hospital, ${ }^{47}$ while in San Damián the poor were fed. Inasmuch as they provided assistance, these can be said to have fulfilled their function. ${ }^{48}$ The remote town of Tauca seems to have been the exceptional case with an active rural hospital although, lamentably, I have found no information that explains why. ${ }^{49}$

Three elements can explain the sombre image that the emissaries of the archbishop presented: the lack of confidence that the hospitals inspired in their supposed beneficiaries, the conduct of the corregidores, and conflicts of jurisdiction. From the time of Jerónimo de Loayza, first archbishop of Lima, it was known that the Indians refused to enter the hospital because of the fear it instilled in them. The Indians referred to the hospital as 'the house of the dead'. This attitude was not limited to the indigenous population of Lima. Among the reasons for rejecting the hospitals given in 1567 by the curacas of Chucuito were inadequate diet and hygiene: the curacas said that they preferred to stay in their homes, where they could eat their fill, and which were not so full of lice. ${ }^{50}$ In 1586 , in response to the questionnaire sent by the Crown which would result in the Relaciones Geográficas de Indias, the corregidores of Atunsoras, Atunrucana, and Laramati, in the province of Huamanga, also registered the Indians' refusal to turn to the hospitals. ${ }^{51}$ In addition to the cultural differences surrounding the treatment of illness, for many curacas and heads of kinship groups, the insinuation that they were not capable of supporting their relatives and subordinates and providing for their needs could be seen as an affront to their authority.

The negative image of the corregidores given in Lobo Guerrero's report comes as no surprise. Some of them appropriated the community money earmarked to support the hospital, and there was no need for them to be in remote places to do so: in Magdalena, on the outskirts of Lima, the corregidor gave nothing to the people of the town. ${ }^{52}$ Others limited themselves to the sporadic distribution of some goods among the sick. Some of the corregidores who responded to the questionnaire of the Relaciones Geográficas gave reports in which they presented themselves in quite a favourable light. In 1586 Diego

\footnotetext{
46 This was the case of Huarmey, a town situated on Peru's central coast. The records of archbishop Mogrovejo's pastoral visitation listed a hospital and a parish church in poor condition, whereas the inspectors sent by archbishop Lobo Guerrero, Mogrovejo's successor, noted that Huarmey had neither hospitals nor confraternities. Benito, op. cit. (note 43), 423-4; Lissón, op. cit. (note 39), Vol. 5: 263.

${ }^{47}$ Lissón, op. cit. (note 39), Vol. 5: 271.

${ }^{48}$ Lissón, op. cit. (note 39), Vol. 5: 282.

${ }^{49}$ Lissón, op. cit. (note 39), Vol. 5: 303.

${ }^{50}$ Diez de San Miguel, op. cit. (note 1), 118.

${ }^{51}$ Marcos Jiménez de la Espada, Relaciones Geográficas de Indias, Perú [Geographical Descriptions of the Indies, Peru], 3 vols (Madrid: Atlas, 1965), Vol. 1: 225, 234.

52 Lissón, op. cit. (note 39), Vol. 5: 268.
} 
Dávila Briceño, corregidor of Yauyos, asserted that not only had he been busy carrying out the reducción of the province's Indian towns, but in practically all of them he had established hospitals endowed with livestock that their encomendero had left them. These were staffed by indigenous specialists whom Dávila Briceño said had been taught some curative techniques such as bloodletting. ${ }^{53}$ In 1582 the corregidor of Jauja, Andrés de Vega, noted that the hospitals of this province were supported by the tomín de hospital in addition to alms. ${ }^{54}$ While these initiatives were indeed taken, their impact was negligible. Instead, there prevailed the idea that the corregidores were a hindrance rather than a help. In the years that followed, the hospitals disappeared, or they took a different direction from the one that was originally intended.

The conflicts of jurisdiction were manifested not only in the tense relations between parish priests and corregidores, or between the latter and the bishops. To these were added the difficult relations with the religious orders, which resisted the controlling impetus of the bishops. In 1619 the Dominicans in charge of the parishes of Yauyos refused to permit the archbishop's emissaries to make an inspection visit, nor would they provide information about their parishioners. In the corregimiento of Huamalíes, the inspectors found a similar attitude among the friars of La Merced. ${ }^{55}$

That same year, Pedro de Valencia, bishop of La Paz, described the state of the hospitals of the Chucuito province, then under his jurisdiction. ${ }^{56}$ Valencia relates that each of the seven towns of the province had a hospital in a house equipped for that purpose. In addition to the tomin, the hospitals, partly following the pre-Hispanic model of provisioning from the resources of the province, were allotted the harvests of maize that came from the distant lowlands of Moquegua and Larecaja. ${ }^{57}$ To this was added the income produced by some general stores. Three surgeons were given charge of attending the inhabitants of the seven towns. In each of these, notes Valencia, there was an Indian barber. ${ }^{58}$ On the surface, the 'hospital network' of Chucuito suggested an unusually good degree of organisation. But the bishop's report did not end there. Valencia lamented that the chief administrator of the hospitals was a layman appointed by the viceroy who, maintaining that the hospitals were under the Patronato Real, would not allow the bishop to visit them and took advantage of the situation to make a profit. The hospitals were precarious and the Indians refused to use them, since they preferred to cure themselves in their homes and rely on the native specialists. According to Valencia, the only acceptable institution was the hospital staffed by the Jesuits in the Indian parish of Juli, where it seems medical attention was offered. ${ }^{59}$

Valencia's description allows us to form an approximation of what happened in the hospitals of Chucuito in the half-century that had passed since the visit of Diez de San Miguel. He had proposed that a hospital be established in Juli, and that the barber who lived in Chucuito, who was paid with the proceeds from the rental of the community's general stores, periodically visit the people in their towns ${ }^{60}$ Fifty years later the hospital of Juli, now administered by the Jesuits, was not the central establishment envisioned by

\footnotetext{
53 Jiménez de la Espada, op. cit. (note 51), Vol. 1: 158-9.

54 Jiménez de la Espada, op. cit. (note 51), Vol. 1: 172.

55 After visiting the province of Yauyos, the inspectors wrote, 'the Indians never come to these hospitals'. Lissón, op. cit. (note 39), Vol. 5: 284.

56 'Relación de Chucuyto' [Report on Chucuyto] by Pedro de Valencia, bishop of La Paz. British Library, Ms. AD13977, f. 519.

57 Diez de San Miguel, op. cit. (note 1); John Murra, op. cit. (note 1), 205.

58 Valencia's observation that the barbers were Indians suggests that the surgeons were probably Spanish.

${ }^{59}$ Valencia, op. cit. (note 56).

${ }^{60}$ Diez de San Miguel, op. cit. (note 1), 220.
} 
Diez de San Miguel. Instead, there was a hospital in each town, in accordance with the proposal of some of the curacas and local notables, who had been questioned in $1567 .{ }^{61}$ Valencia harshly criticises the indigenous authorities to the extreme of recommending their extinction, but he does not say that they participated in the running of the hospitals. ${ }^{62}$ What draws attention in the description of 1619 are the lay administrator, his alleged business dealings with the community's produce, his refusal to allow the Church to inspect the hospitals, and the apparent absence of the curacas. Chucuito shared some of these features with other Indian hospitals in colonial rural Peru.

A first conclusion that can be drawn from the examination of the documents on Indian hospitals is that the curacas and other authorities like native notables, governors, and bosses participated actively in their management. To the degree that they claimed responsibility for the care of the poor as an inherent aspect of their investiture, this stance can be read as the resigned acceptance of a fait accompli, but it could also have been a strategy. The provision of assistance to the poor involved not just the community revenues but also the authority of the curacas. However, if the curacas - or at least some of them - cooperated, we could explain the empty and abandoned hospitals because, of the possible models for a hospital, they chose the one that would not oblige the sick and the needy to abandon their homes. This model could be more easily adapted to local customs and possibilities and to their political culture. The parish priests and the archbishop Mogrovejo himself had to allow it, because this type of assistance was common in the rural Spain of the Ancien Régime. ${ }^{63}$

\section{Financing the Hospitals Effectively}

As one would expect, the question of hospital assets was the thorniest. The collection of the tomin should have generated not-insignificant sums, but a considerable portion did not reach its destination, since it tended to remain in the hands of those who administered it. This tendency only worsened in the decades that followed. The questioning of the composition of the tithe that the Indians paid must have affected the collection of the tomín de hospital, as can be deduced from the memorias de gobierno (reports made to their successors) of the viceroys. Since a portion of the tithe was allocated to the hospitals, some considered the tomín to be redundant. ${ }^{64}$ By the end of the eighteenth

61 The Indians of the Anansaya kin group in Chucuito stated that, 'it would be good to build a hospital in each town, but not establish one single hospital for the whole province because the patients won't be able to make use of it'. Diez de San Miguel, op. cit. (note 1), 87.

${ }^{62}$ Bishop Valencia accused the caciques of being rebellious, idolaters, and of antagonising the parish priests. Valencia, op. cit (note 56).

63 On health care in rural Spain under the Ancien Régime see Luis Alfonso Alcarazo García. La asistencia sanitaria pública en el Aragón rural entre 1673-1750. Las conducciones sanitarias de Barbastro [Public Health Assistance in Rural Aragon from 1673 to 1750. The Contracts to Provide Health Services in Barbastro] (Zaragoza: Institución Fernando El Católico, 2010); Luis S. Granjel, La medicina española renacentista [Spanish Medicine in the Renaissance] (Salamanca: Universidad de Salamanca, 1980); Anastasio Rojo Vega, Enfermos y sanadores en la Castilla del siglo XVI [Patients and Healers in Sixteenth-Century Castile] (Valladolid: Universidad de Valladolid, 1993). On the diverse forms of social assistance and health care in Europe, see Peregrine Horden, 'Household care and informal networks: comparisons and continuities from antiquity to the present', in P. Horden and R. Smith (eds), The Locus of Care: Families, Communities, Institutions and the Provision of Welfare Since Antiquity (London: Routledge, 1998), 21-67.

${ }^{64}$ Since the late sixteenth century representatives of the Indians submitted requests to decrease the amount of contributions paid to the Church. This is why fifty years later the colonial government tried to reduce the contributions already included in the tithes. The Church fiercely opposed this initiative. Hanke and Rodríguez, op. cit. (note 31), Vol. 4: 122-3. 
century, the tomin income to the hospital of Santa Ana in Lima was insignificant. ${ }^{65}$ On the local scale, the assets with which the hospitals had been supported were those that the Toledan regulations described as 'community'. In various towns in the diocese of Lima, the curacas and the other indigenous authorities assumed the duties of mayordomos (stewards) and administrators of the hospitals. From this position, they kept watch over indigenous interests, although certainly there were those who benefitted personally from this. Along the way, they lacked neither confrontations nor the option to establish alliances, since pressure on hospital assets came from various directions.

The locality of Marca in the corregimiento of Huaylas was one of the places where the envoys of Lobo Guerrero in 1619 had described the hospital as a 'deserted house'. ${ }^{66}$ So laconic a report sheds little light on what took place. Thus one might suppose that the inhabitants of the place had abandoned the hospital to its fate, but for a complaint brought by the curacas before the ecclesiastical courts in 1597, which informs us that its facilities - which also included a chapel - had been seized and ruined by the mayordomos of a powerful rancher and landowner of the province, who used them to house livestock and warehouse wool. ${ }^{67}$ In their formal complaint the curacas not only mentioned the services that had been provided in the facilities, but also alluded to the sacred character of the place. In this region, dominated by ranches and textile workshops, the continuous siege by the landowners on Indian property and labour could have contributed to the ruin of the hospitals. Pressure also came from the parish priests, with requests for loans and donations to meet needs that were as much symbolic as material. In 1622 the mayor of Picamarca, Yauyos, who was also the mayordomo of its hospital, asked for and was granted an order that the town be reimbursed a sum of money that the curate of their parish had taken and deposited in a bank in the city of Lima. ${ }^{68}$ The following year, the curacas of San Pedro de Pilas, in Yauyos, demanded the return of the livestock that the parish priest had requested as a loan to alleviate the needs of a neighbouring parish. Three years before, their priest had imposed on them a term of twenty days in which to buy a low canopy under which to carry the viaticum to the sick. Under the exigency of the deadline, the curacas and other leading residents of the town pleaded with the ecclesiastical inspector to authorise them to take money from the hospital funds. When the state of the hospital's assets was examined, it was discovered that the livestock had not been returned, and the canopy had never been purchased. Many resources must have been dissipated owing to the multiple demands that burdened the pueblos, the comings and goings to the courts to file complaints and obtain a response, and the near-impossibility of fulfilling obligations under conditions of asymmetrical social relations. ${ }^{69}$

The cases brought before the ecclesiastical tribunal concerning the administration of hospital property show that the institution had an impact on the economy as much as on local structures of authority. In 1609 the curaca of Orcotuna, in the province of Jauja, and

\footnotetext{
65 David P. Cahill, 'Financing Health Care in the Viceroyalty of Peru: The Hospitals of Lima in the Late Colonial Period', The Americas, 52, 2 (1995), 123-54.

66 Lissón, op. cit. (note 39), Vol. 5: 308.

${ }^{67}$ Archivo Arzobispal de Lima (from now on AAL), Hospitales, leg. 1, exp. 1. Archbishop Mogrovejo's inspection records document the presence in the region of a Garci Barba, head of a powerful family that owned land, ranches, and a sugar cane plantation. Benito, op. cit. (note 43), 19, 29, 376-9.

68 This was the bank owned by Juan de la Cueva, a noted financial institution in the seventeenth century. AAL, Hospitales, leg. 2, exp. 2.

69 The curacas stated during the investigation on this case that 'the parish priests usually take for themselves the property and livestock belonging to the hospitals'. AAL, Hospitales, leg. 2, exp. 8.
} 
other authorities of several towns accused the administrator of the hospital's livestock of a series of offenses that ranged from using the labour of the shepherds for his own benefit, to selling the livestock at prices disadvantageous to the community, to 'giving banquets and clothing', to filing lawsuits indiscriminately. As a result, they maintained, the hospital could neither fulfil its purpose nor carry out the intentions of the encomendero who had founded it. The declarations of the accusers suggest that they thought that the post should be filled by someone who would at least have the approval of the curacas as well as possess wealth of his own, an aristocratic conception of the position. The possibility of making use of the resources of the hospital to supplant the role of the curacas must have provoked alarm and disapproval. ${ }^{70}$ To receive official confirmation in the position of administrator from the Spanish authorities became an objective of some indigenous authorities. After the administrator of the hospitals of Yauyos renounced the position, the Indian leaders took the reins, by decision of their parish priest. Two years later, in 1629, they asked that the archbishop endorse the appointment. To defend their cause, they modified history in their favour, and defended the original plan of the hospitals: they maintained that since the time of Archbishop Loayza it had been customary for the hospitals to have Indian mayordomos, and asserted that if they were given charge, there would be no Spaniards and clerics despoiling the poor of their property. ${ }^{71}$ Although we do not know the disposition of this particular case, it is clear that some curacas came to consider the administration of the hospitals to be an integral aspect of their duties. The fact that the buildings or spaces called hospitals for the most part did not exist was beside the point, since the objective was the assistance that was offered to the needy in their homes. The recourse to the ecclesiastical courts in these parishes in the diocese of Lima suggests that the curacas resorted to it whenever it was suitable or expedient. In the case of Yauyos, because the founder of its hospitals - the archbishop Loayza - was a member of a religious order, the Church acted as mediator in the conflicts over hospital property, which were drawn as much from within as from outside of the communities. But this was not necessarily the case in the other jurisdictions, such as Jauja. ${ }^{72}$ In the last instance, the indeterminate boundaries of the jurisdictions were of considerable import in the towns' disputes over the hospitals' assets.

\section{State, Church, and Indian Hospitals in the Seventeenth and Eighteenth Centuries}

It is clear that the Indian hospitals did not follow a smooth upward path from simple, precarious institutions to organised establishments that accomplished the objectives their creators had assigned to them. The jurisdictional conflicts, the administrative problems, and the presumption that in the best of cases the hospitals were barely a shadow of what their founders had imagined they would be must have awakened doubts among the high-ranking civil and ecclesiastical authorities about their viability as an instrument of government. The assets of the rural and provincial hospitals continued to serve as an object of controversy and different actors, including the viceregal government, the Church, the

70 AAL, Hospitales, leg. 1, exp. 9.

71 AAL, leg. 2, exp.13, 1629.

72 On the question of church jurisdiction over rural hospitals, see Juan Bautista Lassègue, 'La fundación progresiva de un convento-hospital en Parinacochas, diócesis del Cuzco, 1567-1586. Apuntes de lectura e hipótesis de estudio [The Gradual Founding of a Convent-Hospital in Parinacochas, Cuzco Diocese, 1567-1586:

Some Notes and a Hypothesis]', Revista Andina [Andean Review], 4 (1984), 487-512. 
administrators and the indigenous authorities, held different perceptions of the nature of the hospitals' revenues and how they should be administered.

While in the sixteenth century and the beginning of the seventeenth century the highranking authorities of the Lima diocese took note of the Indians' refusal to patronise the hospitals and blamed the corregidores for appropriating their resources, later on the accusations of the abandonment of these establishments and the disappearance of their assets would fall upon the parish priests, but above all on the Indians themselves. This propensity was exemplified in the investigation of the assets of the hospitals of Yauyos that was ordered by the visitador (inspector) Juan Sarmiento de Vivero in 1660. The cleric he sent to investigate stated that the inquiry was necessary because, during a recent epidemic, many people had died of hunger because they had no meat with which to feed themselves. The clergyman enquired what had happened to the hospitals' livestock, and concluded that it had been dissipated

by the bad administration and carelessness of the priests the malice of the Indians and greed of the caciques and governors to profit from the livestock attending only to their [personal] interests and not to the common good have consumed the greater part of the herds of the said hospitals and in this town of San Jerónimo de Omas with little fear of God and with grave harm to their consciences have destroyed the hospital's flock of sheep of Castile without leaving a single head.... ${ }^{73}$

Except for mestizos and Spaniards, about whose presence in the province we have no information, practically no one was safe from criticism. What little that has survived of the questioning of the curacas indicates that the assets of the hospitals had been confused with those of the parish, finally 'disappearing' or possibly remaining in the hands of a few. The building designated as the hospital was in ruins. The allusion to the 'common good' in the words of the diocesan representative indicates a significant change with regard to the values that were expected of the curacas and leaders as those evidently now responsible for the hospitals. Yet to be unequal to the task was a position that discredited them.

While it cannot be said with certainty that there is a direct connection, cases like this must have influenced the changes that took place in the years that followed. In his memoria de gobierno, the viceroy-archbishop Melchor Liñán y Cisneros (1678-81) wrote about the need to strengthen the big hospitals and praised the religious orders dedicated to hospital care. In recommending measures for financing the hospital of Santa Ana in Lima, he explains that by a royal order issued in 1666 the tomin tax had been amended and removed because 'the hospitals have died out and come to an end in the Indian reducciones' ${ }^{74}$ although he acknowledged that in some provinces the corregidores continued to collect it. The predecessors of Liñán y Cisneros had favoured urban hospitals and they entrusted them to the Bethlehemites and the order of San Juan de Dios, both hospital orders, ${ }^{75}$ with the idea that not only would they improve hospital administration, but also that their ethos would inspire a kind of spiritual renewal. Following this lead, Liñán y Cisneros reports that he placed the hospital in Huanta in the hands of the Bethlehemites.

\footnotetext{
73 AAL, Hospitales, leg. 2, exp. 25, 1660.

${ }^{74}$ Hanke and Rodríguez, op. cit. (note 31), Vol. 5: 208.

75 The religious order of the Bethlehemites, devoted to the care of the poor, was founded in Guatemala in the seventeenth century and rapidly spread throughout Spanish America. There are few historical studies about the Bethlehemites. See for example Carlos Mayo, Los betlemitas en Buenos Aires: convento, economía y sociedad, 1748-1822 [The Bethlehemites in Buenos Aires: Convent, Economy, and Society, 1748-1822] (Sevilla: Excelentísima Diputación de Sevilla, 1991). There is no historical study about the order of San Juan de Dios in the Andes. For Mexico, see Solange Alberro, Apuntes para la historia de la Orden Hospitalaria de San Juan de Dios en la Nueva España-México, 1604-2004 [Notes for the History of the Hospital Order of Saint John of God in New Spain-Mexico, 1604-2004] (México: El Colegio de México, 2005).
} 
A judicial proceeding initiated by the curacas of Huanta in 1756 to claim possession of their hospital permits us to glimpse the effects of these changes. ${ }^{76}$ This hospital must have been founded in the sixteenth century according to a bequest in the will of the encomendero who left property and a sum of money by way of restitution to the Indians of three communities of Huanta. A copy of the will remained in the community treasury and, many years later, the viceroy Marqués de Mancera (1639-48) authorised the hospital's founding. It was stipulated that under the supervision of the Jesuit rector a house be purchased to house the hospital, and the protector de naturales was placed in charge of its administration. But after a period of time the hospital was abandoned and its rental income was adjudicated to the hospital of Huamanga, administered by the religious order of San Juan de Dios. It is not evident that the placement of the Huanta hospital in the care of the Bethlehemites that had been ordered by Liñán y Cisneros was ever carried out. In 1756 the claim of the curacas of Huanta for the restoration of the hospital and its property to their locality was made against the town council of Huamanga and the order of San Juan de Dios. They presented the evidence of the encomendero's bequest and explained that, due to the distance, the Indians of their communities could not be treated in the hospital in Huamanga. The court decided that, until the hospital in Huanta was rehabilitated, the hospital in Huamanga would continue in possession of its resources. Thirty years later the dispute was still going on, but now the religious of San Juan de Dios considered it a grievance that anyone from Huanta was attempting to assert some claim to this property. By this time, the curacas had disappeared from the scene and it was the curate of Huanta who was pursuing the case. ${ }^{77}$ Comparable situations occurred in other localities where the government favoured the religious orders, handing the income of the hospitals over to them, to the detriment of the communities. ${ }^{78}$ In the years that followed, the Crown sought to ensure that the royal courts would be able to oversee the hospitals that were in the hands of the religious orders by, first, asserting that these were still subject to the Patronato Real and, second, curbing the religious orders' ambitions to appropriate the assets of the hospitals. $^{79}$

The reforming impetus of the Bourbons also reached the administration of the hospitals. ${ }^{80}$ A trial that took place around $1748^{81}$ brings us back to the province of Chucuito to examine how hospital assistance was organised in the century after the 1619 report of the bishop Valencia. The arguments used permit us to analyse different perceptions of the nature of the hospitals, the role that fell to the government at the moment in which it was trying to reform the colonial administration, the participation of the curacas and other indigenous authorities in the provision of aid, the fate of the tomin and of the community funds, as well as the participation of the Church.

The trial was conducted before the Superior Gobierno (central government) beginning with a report by the officials of the royal treasury against Ignacio de las Cuentas, administrator of the tomín de hospital in Chucuito and the protector de naturales there.

\footnotetext{
76 AGN, Derecho Indígena, leg. 17, c.291, 1756.

77 AGN, Derecho Indígena, leg. 23, c. 396, 1781.

78 AGN, Derecho Indígena, leg. 24, c. 442, 1790.

79 Juan Joseph Matraya y Ricci, Catálogo cronológico de las pragmáticas, cédulas, decretos, órdenes y resoluciones reales generales emanados después de la Recopilación de las Leyes de Indias [A Catalogue Organized in Chronological Order of the Laws and other Regulations Produced after the Compilation of the Laws of the Indies] (Buenos Aires: Instituto de Investigaciones de Historia del Derecho, 1978), 259.

${ }^{80}$ Cahill, op. cit. (note 65).

${ }^{81}$ AGN; Derecho Indígena, leg. 16, c. 278, 1748.
} 
The relevance of his position and salary was questioned, since a hospital no longer existed in this province. The case had come to light several years earlier, when in 1738 a decree ordered that De las Cuentas cease to administer the money from the tomín, and deposit it in the royal treasury. He was also commanded to return any salary that he had collected since the decree had been issued.

In his defence, the administrator tried to show that the royal officials had incorrectly interpreted the nature of the tomin, the rights and responsibilities it involved, and its administration. He maintained that the tomin de hospital, created to address the health needs of the Indians, did not belong to the king, but rather was 'the Indian's own wealth, which must be turned to the benefit of this same Indian when he is sick', thus the directive to deposit it in the royal treasury was unlawful. He also recalled that, by law, the tomin was collected by the corregidores and alcaldes mayores (district magistrates) of the towns, and that in the case of Chucuito, from 'time immemorial' the protector de naturales had been responsible for its administration. The administrator argued that the tomín served to help the Indians who did not live in the cities, which set aside the well-established role of the community funds, and he went on to explain the notion of the hospital that applied in the province. The tomin - he declared - was paid not 'for the walls of the hospital' but rather so that the Indians would receive medical attention. He acknowledged that there was no hospital in Chucuito, but he maintained that this mattered little, because the Indians indeed received assistance. To have a hospital in a central location was impractical because, apart from there not being sufficient means to support one, great distances would have to be travelled by those who needed it. As for the hospital that the Jesuits ran in Juli, it did not count, since it only served the people of that parish. De las Cuentas explained that he himself delivered the help and, moreover, in each town he had 'trustworthy persons' - curacas and local leaders - who were in charge of distributing food and medicine to those in need. The parish priests participated in the system, issuing vouchers to the caciques for modest quantities which were delivered individually. ${ }^{82}$ This adaptation of the local conditions, which of necessity recognised the role of the indigenous authorities, made the system viable.

It is impossible to know how effective the organisation described by De las Cuentas was. It is probable that, as had happened in other provinces, the money did not arrive in the amounts hoped for by those for whom it was intended, but undoubtedly the arguments presented sum up a practice that the government authorities as well as the ecclesiastics, in their zeal to impose their model of assistance, repeatedly refused to recognise. The result of this trial is surprising, since the government ruled in favour of the administrator, admitting that, although 'there was no hospital in the material sense, it did exist in [another] form'. It may have been difficult for De las Cuentas to imagine that the effects of the imperial policies of the Bourbons would prevent him from receiving justice and recognition of his work as an agent of the government. Yet when he asked for the return of the money that he had been obliged to restore to the royal treasury, the only response he received was that it was impossible, because 'it had been consumed by the costs of the war'.

\section{Conclusion}

Assistance to the poor was one of the pillars upon which the monarchy supported its efforts to legitimate its right to govern. In Spanish America, this principle was applied to

\footnotetext{
82 The trial records contain statements given by curacas, other indigenous authorities, and parish priests confirming that social assistance in Chucuito was provided as described.
} 
the governance of the Indians, conceptualising them as miserables (wretches) and the king as 'patron of the poor' or 'protector of the Indians'. From this point of view, the Indian hospital must have been an instrument of government through which the role of the king was made tangible, creating a bond between the king and his subjects which was replete with the political and not a little of the sacred. The Church formed part of this bond, sometimes confirming it, and other times challenging it, depending on the circumstances in which it could intervene, siding with or mediating between one party and another. In practical terms, this nexus was made possible by means of the contributions of the (supposed) beneficiaries themselves.

In light of the diversity of forms encompassed by the notion of the hospital that was transplanted to the Andes, it should not seem odd, after having been established for so many years, that how hospitals ought to be, the nature and purpose of the tax created to support them, and the manner in which they were administered were fuel for controversy. In between there had been not only different interpretations and practices of health and mutual aid but also, as I have tried to show here, of authority, and of who should wield it and how. That is to say, through which channels would the protective power of the king flow, and how would these be directed to the native population: what role would be played by the corregidores, protectores de naturales, parish priests, the communities, and indigenous authorities, as vehicles for and administrators of authority. The role of the curacas was the most controversial point. Upon their participation depended the success or failure of the provincial hospitals and those of the Indian parishes. The project of creating systems of public assistance or hospitals assumed that it was necessary to bypass the indigenous authorities and weaken the bonds of kinship so that the hospitals, understood as places of isolation, could prosper. This entailed the transformation of their users into authentic miserables. Attempts to impose this institutional model failed not only because of the refusal of the curacas and the indigenous population to adopt it, but also because, in the end, the parish priests as well as the provincial colonial authorities recognised that, without the cooperation of the curacas the project was not viable. It was the local administration of hospitals, and most importantly, the fact that these same communities together with their resources supported the actions of assistance, that tended to strengthen the authority of the curacas. But the power of the latter was far from stable, depending as it did on conditions that, as much from within as from outside the communities they headed, had influence on their cohesion, their social hierarchy, and their ability to safeguard their wealth. The actions of encomenderos, landowners, ranchers, parish priests, and religious orders, and the processes of socioeconomic differentiation within the indigenous population, exerted a fundamental pressure on the shaping of the communal institutions of which the hospital formed a part. Finally, outside the cities, the colonial State lacked the human and financial resources and suffered from political limitations too serious to be able to execute its project of assistance as it had originally been conceived. 